\title{
127. Effects of Peptides on the Release of Catecholamines and Adenine Nucleotides from Cultured Adrenal Chromaffin Cells
}

\author{
Mastoparan-Induced Release \\ By Yoichiro Kuroda,*) Masanori YoshioKA,**) \\ Konosuke KumaKURA,***) \\ Kazuo Kobayashi, ${ }^{*}$ ) and Terumi NaKaJIMA****) \\ (Communicated by Teizo OGAWA, M. J. A., Dec. 12, 1980)
}

Chromaffin cells in adrenal medulla release catecholamines, ATP and other granular contents in the exocytotic manner by nerve stimulation ${ }^{1)}$ and are well known as a model system of stimulation-secretion coupling. An analogy of this type of hormone release has been applied to the release of neurotransmitters from presynaptic nerve terminals. In order to investigate the molecular mechanism of stimulation-secretion coupling, these chromaffin cells are considered to be the most suitable system.

Findings of specific toxins or agents have developed the studies on dynamic mechanisms of biological phenomena (for example, tetrodotoxin, $\alpha$-bungarotoxin and historionicotoxin for the studies on neurotransmission). Mastoparan is a mast cell degranulating peptides which was isolated from the venom of Japanese wasp, Vespula lewisii and characterized chemically as tetradecapeptide amide.2) Granuliberin $\mathrm{R}$ is a dodecapeptide amide, which also has a mast cell degranulating activity, isolated from the skin of frog, Rana rugosa. ${ }^{3)}$ Mastoparan has been known to act only on the mast cell and release histamine from the cell. In artificial black membrane, conductivity of $\mathrm{Ca}^{2+}$ or $\mathrm{K}^{+}$was increased more than 100 fold by the addition of $1 \mu \mathrm{g} /$ $\mathrm{ml}$ of mastoparan on both sides of the membrane.4),5) This suggests that the mode of action of mastoparan depends on the property of the ionophore or ion channeling toward the lipid bilayer. The peptide may act perpendicularly on the mast cell membrane and change the concentration of $\mathrm{Ca}^{2+}$ or $\mathrm{K}^{+}$in the cell and stimulate the release of his-

*) Department of Neurochemistry, Tokyo Metropolitan Institute for Neurosciences, Fuchu-shi, Tokyo 183.

Tokyo 113.

**) Faculty of Pharmaceutical Sciences, University of Tokyo, Bunkyo-ku,

***) Life Science Institute, Sophia University, Chiyoda-ku, Tokyo 101.

****) Institute of Medical and Dental Engineering, Tokyo Medical and Dental University, Chiyoda-ku, Tokyo 101. 
tamine. If this mechanism is true, mastoparan would work other secreting cells and appear to be a good tool to investigate the process of exocytosis.

This study was carried out to know whether these peptides also cause the release of catecholamines and adenine nucleotides from the chromaffin cells.

Materials and methods. Mastoparan and granuliberin $\mathrm{R}$ were isolated and purified as described previously. ${ }^{2), 3)}$

Adrenal chromaffin cells were isolated from fresh bovine adrenal glands and cultured by a modification ${ }^{6)}$ of the methods described by Waymire et al. ${ }^{7)}$ Briefly, the isolation procedure consists of ; dissection of the adrenal medulla from the cortex, digestion of the interstitial tissue of adrenal medulla by retrograde perfusion with $0.25 \%$ collagenase (Sigma, Type I) to dissociate the cells, differential centrifugation and filtration, and differential plating to remove non-chromaffin cells. The differential plating was repeated twice to keep the contaminant cells less than $2 \%$. The purified chromaffin cells were cultured in minimum essential medium (GIBCO 410-1200), 10\% fetal calf serum (GIBCO), penicillin (100 units $/ \mathrm{ml})$, streptomycin (100 $\mu \mathrm{g}$ ) $\mathrm{ml})$, fluorodeoxyuridine $(10 \mu \mathrm{M})$, cytosine arabinoside $(10 \mu \mathrm{M})$, uridine $(5 \mu \mathrm{M})$ and mycostatin (GIBCO, 25 units $/ \mathrm{ml}$ ).

For release studies, approximately $10^{6}$ cells were washed once with warmed standard medium and suspended in $1 \mathrm{ml}$ of the medium. The standard medium consisted of Krebs-Ringer salt solution, $20 \mathrm{mM}$ HEPES, $10 \mathrm{mM}$ glucose, $2.0 \mathrm{mM} \mathrm{CaCl}_{2}$ and $0.5 \%$ bovine serum albumin. The $\mathrm{pH}$ of the medium was adjusted 7.2-7.4 by the addition of $1 \mathrm{~N} \mathrm{NaOH}$.

The release of endogenous catecholamines and adenine nucleotides from the cultured chromaffin cells was measured by incubating the cell suspension at $37^{\circ} \mathrm{C}$ for $3 \mathrm{~min}$ with or without the addition of peptides. After the incubation the cell suspension was filtered through a Millipore filter. The filtrate was added $100 \mu \mathrm{l}$ of $5 \mathrm{M}$ perchloric acid and centrifuged at $1000 \times \mathrm{g}$ for $10 \mathrm{~min}$ to remove protein precipitate. The supernatants were immediately frozen and kept at $-20^{\circ} \mathrm{C}$ until the assays by high pressure liquid chromatography (HPLC).

The HPLC for adenine nucleotides was carried out according to a method described by Yoshioka et al. ${ }^{8)}$ A hundred $\mu$ l of the supernatant stored was neutralized with $100 \mu \mathrm{l}$ of $1 \mathrm{M} \mathrm{KHCO}_{3}$. The precipitated $\mathrm{KClO}_{4}$ was centrifuged off. Fifty $\mu$ of the supernatant was added an equal volume of $0.2 \mathrm{M}$ phosphate buffer, $\mathrm{pH} 7.0$ and $10 \mu \mathrm{l}$ of $1.9 \mathrm{M}$ bromoacetoaldehyde. The solution was heated at $80^{\circ} \mathrm{C}$ for $15 \mathrm{~min}$. Five $\mu \mathrm{l}$ of the solution reacted was analysed by HPLC. ${ }^{8)}$

The HPLC for catecholamines was carried out as follows. One $\mu$ l 
of the supernatant stored was directly injected to a chromatograph. The column $(0.5 \mathrm{~mm} \times 13 \mathrm{~cm})$ of Hitachi gel No. 3011-c (Nissei Sangyo Co. Ltd., Tokyo) was run at $45^{\circ} \mathrm{C}$. The flow rate of an eluent of $0.4 \mathrm{M}$ acetate buffer, $\mathrm{pH} 4.0$, was set at $10 \mu \mathrm{l} / \mathrm{min}$ by a micropump Familic 100-N (JASCO, Tokyo). The column inlet pressure was $5 \mathrm{~kg}$ / $\mathrm{cm}^{2}$. The eluate was monitored by a fluorescence spectrophotometer FP-110 (JASCO, Tokyo). The spectrophotometer was equipped with a low-pressure mercury lamp of the maximum energy at $253.7 \mathrm{~nm}$. The excitation and emission wavelengths were set at $253.7 \mathrm{~nm}$ and $324 \mathrm{~nm}$ respectively.

Results and discussion. As shown in Table I, mastoparan $(10 \mu \mathrm{g} / \mathrm{ml})$ increased the release of both catecholamines and of adenine nucleotides from cultured adrenal chromaffin cells. In contrast, a similar histamine-releasing peptide, granuliberin $\mathrm{R}$, at the same concentration did not change significantly the basal release of both compounds. This indicates that the stimulation of release by mastoparan is very specific and has different mechanism from that by granuliberin $\mathrm{R}$.

Table I. Effects of peptides on the release of catecholamines and adenine nucleotides from cultured aderenal chromaffin cells

\begin{tabular}{|c|c|c|c|c|c|c|c|c|}
\hline \multirow{3}{*}{ Addition } & \multicolumn{7}{|c|}{ Release ( $\mathrm{n}$ mole $/ 10^{6}$ cells) } & \multirow{3}{*}{$\begin{array}{l}\text { CA/ } \\
\text { AN }\end{array}$} \\
\hline & \multicolumn{3}{|c|}{ Catecholamines (CA) } & \multicolumn{4}{|c|}{ Adenine nucleotides (AN) } & \\
\hline & $\mathrm{NE}$ & $\mathrm{E}$ & Total & ATP & ADP & $5^{\prime}-\mathrm{AMP}$ & Total & \\
\hline Control (None) & 2.3 & 6.1 & 8.4 & 0.55 & 1.1 & 1.1 & 2.8 & 3.0 \\
\hline $\begin{array}{l}\text { Mastoparan } \\
\text { (10 } \mu \mathrm{g} / \mathrm{ml}) \\
\text { (\% of control) }\end{array}$ & $\begin{array}{l}12 \\
(520 \%)\end{array}$ & $\begin{array}{l}33 \\
(540 \%)\end{array}$ & $\begin{array}{l}45 \\
(540 \%)\end{array}$ & $\stackrel{2.8}{(510 \%)}$ & $\begin{array}{l}7.6 \\
(690 \%)\end{array}$ & $\begin{array}{l}7.3 \\
(660 \%)\end{array}$ & $\begin{array}{l}18 \\
(640 \%)\end{array}$ & 2.5 \\
\hline $\begin{array}{l}\text { Granuliberin } \mathrm{R} \\
(10 \mu \mathrm{g} / \mathrm{ml}) \\
(\% \text { of control })\end{array}$ & $\begin{array}{l}2.2 \\
(96 \%)\end{array}$ & $\begin{array}{l}5.4 \\
(89 \%)\end{array}$ & $\begin{array}{c}7.6 \\
(90 \%)\end{array}$ & $\begin{array}{c}0.44 \\
(80 \%)\end{array}$ & $\begin{array}{l}1.2 \\
(110 \%)\end{array}$ & $\begin{array}{l}1.3 \\
(120 \%)\end{array}$ & $\begin{array}{l}2.9 \\
(110 \%)\end{array}$ & 2.6 \\
\hline
\end{tabular}

Values are the average of two independent experiments.

The spontaneous release of total catecholamines (norepinephrine $(\mathrm{NE})+$ epinephrine $(\mathrm{E})$ ) and of total adenine nucleotides (ATP + ADP + $5^{\prime}$-AMP) were stimulated 5.4 fold and 6.4 fold, respectively, by the addition of mastoparan. There was no detectable release of dopamine even when mastoparan was applied. The ratio of $\mathrm{NE}: \mathrm{E}$ was remarkably similar (Table II), suggesting that both releases were originated from the same subcellular compartment in a similar manner. The basal ratio of ATP:ADP: $5^{\prime}$-AMP $(1: 2.0: 2.0)$ was different from those observed in the mastoparan-treated $(1: 2.7: 2.6)$ and the granuliberin-treated $(1: 2.7: 3.0)$ chromaffin cells (Table II). Relatively more adenine nucleotides released from the peptides treated cells than catecholamines. 
Table II. Ratios of norepinephrine: epinephrine and ATP: ADP: $5^{\prime}$-AMP released from chromaffin cells

\begin{tabular}{lcc}
\hline \multicolumn{1}{c}{ Addition } & $\begin{array}{c}\text { Norepinephrine: } \\
\text { Epinephrine }\end{array}$ & ATP: ADP: $5^{\prime}$-AMP \\
\hline Control (None) & $1: 2.7$ & $1: 2.0: 2.0$ \\
Mastoparan & $1: 2.7$ & $1: 2.7: 2.6$ \\
Granuliberin R & $1: 2.5$ & $1: 2.7: 3.0$ \\
\hline
\end{tabular}

Values are calculated from Table I.

This situation affected the ratio of catecholamines and adenine nucleotides ( $\mathrm{CA} / \mathrm{AN}$ ratio) in mastoparan-treated experiments. The decrease of $\mathrm{CA} / \mathrm{AN}$ ratio by the addition of mastoparan suggests that some adenine nucleotides come out from an intracellular compartment which is different from one for the catecholamine release. Considering the generally-accepted idea that the release of catecholamines and adenine nucleotides from chromaffin cells occurs by the exocytosis of chromaffin granules, this additional release of adenine nucleotides may come from a cytoplasmic adenine nucleotides pool. However, since the amounts of further metabolites of adenine nucleotides (adenosine $e t$ al.) were not determined in these experiments, the relative increase of ADP and 5'-AMP can be explained by the inhibition of further degradation of adenine nucleotides by the peptide treatment. In fact, such degradation of adenine nucleotides was observed in the superfusates from synaptosomes of cerebral cortex. Most of released ${ }^{14} \mathrm{C}$-materials originated from adenine nucleotides pool in the presynaptic nerve terminals was found as ${ }^{14} \mathrm{C}$-adenosine, ${ }^{14} \mathrm{C}$-inosine and ${ }^{14} \mathrm{C}$-hypoxanthine. ${ }^{9)}$ This possibility and further characterization of the peptide-dependent release of chromaffin cell components are being investigated in our laboratory.

A part of this work was supported by a Grant in Aid for Scientific Research 1980 (no. 557505) from the Ministry of Education, Science and Culture.

\section{References}

1) Douglas, W. W. (1975): Handbook of Physiology. Section 7, vol. 6. American Physiological Society, Washington, $367 \mathrm{pp}$.

2) Hirai, Y., Yasuhara, T., Yoshida, H., Nakajima, T., Fujino, M., and Kitada, C. (1979) : Chem. Pharm. Bull., 27, 1942.

3) Nakajima, T., and Yasuhara, T. (1977): Chem. Pharm. Bull., 25, 2464.

4) Okumura, K.: (to be published).

5) Nakajima, T. (1980): Hormones, Adaptation and Evolution (eds. S. Ishii et al.). Japan Sci. Soc. Press, Tokyo/Springer-Verlag, Berlin, 287 pp.

6) Kumakura, K., Kobayashi, K., and Kuroda, Y.: (submitted for publication).

7) Waymire, J. C., Waymire, K. G., Boehme, R., Noritake, D., and Wardell, J. 
(1977) : Structure and Function of Monoamine Enzymes (eds. Usdin, E. et $a l$.$) . Dekker, New York, 327 \mathrm{pp}$.

8) Yoshioka, M., Nakamura, A., Iizuka, H., Nishidate, K., Tamura, Z., and Miyazaki, T. (1980) : Nucl. Acids Res., s8, 61.

9) Kuroda, Y., and McIlwain, H. (1974): J. Neurochem., 22, 691. 